\title{
Plaatsbepaling in de strijd
}

\author{
C. OFFRINGA
}

H. A. Diederiks, M. A. Wes, e.a., Veranderingen in de geschiedwetenschap (OSGN Wetenschappelijke Publikaties nr. 1, november 1973,65 blz.; te verkrijgen bij de quaestor OSGN, Uilenstede 40-236, Amstelveen 1134, gironummer 1653772, prijs $f$ 3,50 excl. portokosten).

Op 9 februari 1973 verscheen in het Cultureel Supplement (CS) van de $N R C$ onder het opschrift 'Historicus in dienst van de vooruitgang 'een bespreking van J. H. Plumbs bundel In the Light of History van de hand van H. W. von der Dunk, hoogleraar in de contemporaine geschiedenis te Utrecht. Von der Dunk constateert hierin dat er zo nu en dan iets in de samenleving vaart 'dat men als een anti-historische allergie, een kleiophobie zou kunnen noemen'. Hij meent tevens dat men dit 'zo nu en dan' gewoonlijk vrij precies kan aangeven:

namelijk altijd dan - zoals nù- wanneer er onvrede heerst met de maatschappelijke en politieke toestanden en ergo behoefte aan hervormingen. Verzet tegen de status quo brengt bij velen als primaire actie ook verzet tegen de geschiedenis met zich mee, die dan wel die status quo niet heilig verklaart, maar toch wel verklaart, in elk geval geestelijke energie verkwist aan de bestudering van zeer dubieuze zaken.

Voorts brengt Von der Dunk in herinnering, dat reeds Nietzsche in de last van het verleden een gevaar voor de creativiteit van onze beschaving zag, maar hij wijst er tevens op, dat Nietzsche 'als klassiek filoloog en Burckhardt pupil doordrenkt was met historisch denken en tot over zijn oren in de Europese cultuur stak' ${ }^{1}$.

In het CS van de NRC van 23 maart 1973 gingen H. A. Diederiks, wetenschappelijk medewerker voor de sociale geschiedenis te Leiden en M. A. Wes, lector in de oude geschiedenis aldaar, in op het oordeel van Von der Dunk, dat 'het driftig actualisme' tekenen van uitputting vertoont, en dat dit ook te verwachten was, want immers 'de geschiedschrijving heeft vele rebellieën overleefd en zal dat ook in de toekomst doen. Uit elke crisis is zij afgeslankt en verjongd te voorschijn gekomen, omdat wat kritiek op het vak leek, in wezen een kritiek was op de wijze, waarop het beoefend werd'. Waarna hij uitdagend uitroept:

Omdat ieder, die het woord 'crisis' in de mond neemt al snel verdacht wordt van defaitisme of pessimisme, wil ik hier luidkeels beklemtonen, dat de interne 'crisis' van het vak - de discussie over methodieken en vraagstellingen - voor mij geen symptoom van verval is maar van vitaliteit.

1. In dit verband een Nietzsche citaat: 'Dies gerade ist der Satz, zu dessen Betrachtung der Leser eingeladen ist: das Unhistorische und das Historische ist gleichermassen fiir die Gesundheit eines Einzelnen, eines Volkes und einer Kultur nötig' (cursief Nietzsche) in: Fr. Nietzsche, 'Unzeitgemässe Betrachtungen. Zweites Stück. Vom Nutzen und Nachteil der Historie für das Leben', Werke, Karl Schlechta, ed. (3 dln; München, 1954) I, 214. 
In hun $N R C$ bijdrage 'Het verleden in de toekomst' betwisten Diederiks en Wes dat de ook door Von der Dunk gesignaleerde 'crisis' conjunctureel zou zijn. Hun diagnose wijst op een structuurcrisis.

Daar zowel Von der Dunk als Diederiks en Wes methodiek èn vraagstelling centraal stellen, rijst de vraag waar een eventuele crisis ophoudt conjunctureel te zijn en structureel wordt, en of de relatie tussen methodiek en vraagstelling wellicht voor het antwoord beslissend zou kunnen zijn. Uit andere publikaties van Von der Dunk ${ }^{2}$ blijkt, dat hij bereid is nieuwe methodieken te accepteren, maar zich keert tegen hen die de 'klassieke' geschiedbeoefening niet wetenschappelijk vinden, omdat zij niet aan het natuurwetenschappelijk wetenschapsideaal voldoet. Blijft het dus 'slechts' een kwestie van methodiek? Neen, want afwijzing van wat men ten onrechte 'litteraire' geschiedschrijving noemt, houdt in dat men diè elementen uitsluit, die een beeld mogelijk maken; ja, zelfs Romeins ideaal, een integrale geschiedschrijving, zou men in dat geval laten varen. Met andere woorden: de pretentie van de nieuwe methodieken is zo absoluut, dat hun al dan niet toepasbaarheid een oordeel schijnt te impliceren met betrekking tot de vraag of een bepaalde probleemstelling wetenschappelijk zinvol is of niet.

De discussie over de zogenaamde crisis in de geschiedwetenschap wordt dan ook niet in de laatste plaats vertroebeld door de vaak nogal onoprecht aandoende verzekering van hoogachting van de kant van de vernieuwers voor de 'gewone' geschiedenis ${ }^{3}$. Want het gaat hun niet in de eerste plaats om een verrijking van onze wetenschap, maar om een radicale wijziging van haar structuur, waarbij methodiek en vraagstelling elkaar weliswaar wederzijds bepalen, maar de methodiek een eigen, dwingend momentum heeft gekregen.

Zoals ik reeds opmerkte: de neiging groeit om alles wat buiten het bereik van de moderne, lees: sociaal-wetenschappelijke methodieken valt, als zinloos weg te wuiven. Men kan dat betreuren, maar dat neemt niet weg dat het onjuist zou zijn om de vraag naar de 'relevantie' van bepaalde historische kennis als een hinderlijke interruptie te negeren. Een serieuze poging tot beantwoording van die vraag heeft echter tot voorwaarde, dat men zich scherp bewust is van de filosofisch antropologische, kennis-theoretische en metafysische implicaties ervan. Het feit dat dit meestal niet het geval is en de deelnemers aan een debat over de grondslagen van ons vak vaak onbewust uitgaan van bepaalde wijsgerige vooronderstellingen die bovendien bij de één overwegend op kennistheoretisch gebied liggen (bijvoorbeeld 'vooral meten geeft weten'), terwijl de ander weer vanuit andere posities redeneert (bijvoorbeeld vanuit de filosofisch antropologische opvatting, dat de mens vrij en blij is), maakt zo'n discussie niet zelden tot een frustrerende spraakverwarring.

Dat deze problematiek voor de historicus doorzichtig moet zijn, is niet alleen voorwaarde voor een discussie zonder irritatie door misverstand, maar vooral ook voor alle geschiedschrijving die die naam waardig is. Immers, in tegenstelling tot de systematische empirische wetenschappen bepalen de filosofische positie van de onderzoeker (uiteraard meestal ongereflecteerd), en vraagstelling en methodiek van het onderzoek elkaar dusdanig, dat van een voor ieder aanvaard studieobject geen sprake kan zijn.

Op grond van het bovenstaande durf ik dan ook de volgende voorspelling te doen: zolang onze samenleving niet in de ban komt van een totalitaire ideologie, die geschiedschrijving slechts duldt voorzover zij zich laat hanteren als instrument voor legitimatie en enculturatie, zal de geschiedwetenschap een hokkerig huis blijven met vele woningen; zoals trouwens reeds Romein zei, toen hij Huizinga in bescherming nam tegen 'wetenschappers' die deze 'aestheet' en 'litterator' niet wetenschappelijk vonden.

2. Zie bijvoorbeeld 'Kleio en de computer', NRC (CS), (4-1-1974).

3. Dit adjectief prefereer ik boven traditioneel. 


\section{OFFRINGA}

Als historicus die zich met overtuiging, maar niet zonder vrees voor pedante geleerdheid, met de aangestipte problemen bezighoudt, meen ik dat de voorgaande beschouwing nuttig kan zijn als achtergrond voor een analyse van de reacties die het artikel van Diederiks en Wes direct en indirect uitgelokt heeft.

Direct reageerde I. Schöffer, hoogleraar in de vaderlandse geschiedenis te Leiden, in het CS van de NRC van 18 mei 1973 in een artikel over 'Twee wegen naar het verleden'. Als indirecte reactie mogen we beschouwen het initiatief van de OSGN om het Leidse woorden-wederwoord met opstellen van andere historici samen te voegen tot de eerste van een geprojecteerde reeks OSGN Wetenschappelijke Publikaties. Het bestuur wilde op die wijze antwoord krijgen op vragen als: 'is er een crisissituatie, hetzij conjunctureel, hetzij structureel; wat is de zin en aard van de geschiedbeoefening etc'.

Daar het Nederlands Historisch Genootschap zelf een congres over deze thematiek voorbereidt en daar bovendien Nederland zal rapporteren over het probleem van de waardeoordelen op het internationaal congres dat in 1975 in San Francisco gehouden zal worden, heeft de redactie van dit tijdschrift mij gevraagd deze bundel bij de lezers in te leiden en er enige kanttekeningen bij te plaatsen. Ik zal mij vooral concentreren op de door de Leidse polemiek opgeworpen vragen, omdat zij door velen - mede door hun betekenis voor de organisatie van onderwijs en onderzoek - als brandend ervaren worden. Daarom zal ik ook bij mijn analyse van wat men al dan niet terecht als crisis aanduidt een interview betrekken, dat een medewerker van de $N R C$ had met twee hoogleraren van de Erasmus Universiteit over hun plan voor een subfaculteit geschiedenis te Rotterdam.

Ik wil beginnen met de inhoud van het stuk van Diederiks en Wes in grote lijnen weer te geven. Diederiks en Wes vonden in Von der Dunks recensie aanleiding om aan een breder publiek voor te leggen de resultaten van een Survey of the Behavioral and Social Sciences, dat tussen 1967 en 1969(4) onder auspiciën van de National Academy en de Social Science Research Council óók onder Amerikaanse historici gehouden is. 'In het onderzoek - aldus Diederiks en Wes - kwamen vragen aan de orde over plaats, functie, ontwikkeling en in verband daarmee de tekortkomingen en wensen van de gedrags- en sociale wetenschappen'. David S. Landes (economisch historicus) en Charles Tilly (socioloog) publiceerden over het onder historici verrichte deelonderzoek in 1971 een boekje onder de titel History as Social Science $e^{5}$. Diederiks en Wes menen dat uit dit verslag een structurele crisis in de geschiedwetenschap blijkt en dat de Nederlandse historici zich in de voorgehouden spiegel zullen herkennen. In verband met 'Posthumus' is - zo zeggen zij - een confrontatie van de Amerikaanse met de Nederlandse situaties gewenst, terwijl bovendien een discussie zin kan hebben voor een groter publiek, 'aangezien kennisneming van het verleden nog altijd geldt als een algemeen aanvaard element in de cultuur van onze samenleving'.

De beide heren geven dan de volgende samenvatting van het Amerikaanse rapport:

De geënquêteerde historici (1001 werden aangeschreven, 63\% daarvan antwoordde) vallen in twee groepen uiteen:

1) 'de meer traditioneel-'humanistisch' georienteerden', die menen dat de maatschappij te ingewikkeld is 'om in eenvoudige, algemene categorieën ondergebracht te worden'; die niet beginnen 'met een van te voren geformuleerde vraagstelling'; die pas in de loop van hun onderzoek tot een nadere omschrijving hiervan komen ('als hij er al toe komt'); en

4. De jaren van Black Power, de mars der armen, Vietnam, de verkiezingsstrijd Nixon-Eugene McCarthy, de onrust op de campussen.

5. David S. Landes en Charles Tilly, ed., History as Social Science (Englewood Cliffs, N. J., 1971). 
zelfs wanneer zij uitgaan van een werkhypothese er de voorkeur aan geven 'dit mooi te verpakken in literair verzorgd proza', en zeker geen knieval zullen maken voor 'het gouden kalf van de Kwantificatie' ${ }^{16}$.

2) 'de sociaal-wetenschappelijk georiënteerden', die uitgaan van een probleemstelling op grond van de premisse dat er bepaalde algemeen-menselijke gedragingen zijn, die niet gebonden zijn aan tijd en plaats en als zodanig bestudeerd kunnen worden; die 'scherp omlijnde definities en werkhypothesen' hanteren, 'die bij voorkeur opgenomen worden in een verklarend model'; die de gegevens uit bronnen toetsen aan dit model en het model aan de gegevens aanpassen ('en niet omgekeerd!'); en die 'graag meten om te weten', omdat 'cijfermateriaal (hen) wapent . . . tegen het gevaar dat toeval in het overgeleverde materiaal en persoonlijk of ideologisch vooroordeel zijn bevindingen ongunstig (sic!) beïnvloeden'. Derhalve dringt zich de vraag op 'of er wel één historische wetenschap is, die gebaseerd is op door historici algemeen aanvaarde onderzoeksnormen en die op eigen wijze gericht is op een voor alle betrokkenen vaststaand onderwerp'. Antwoord: er zijn 'gemeenschappelijke uitgangspunten', want iedereen erkent dat het heden een kind van het verleden is en daarom de noodzaak van historisch perspectief.

Echter: het verleden is oneindig ingewikkeld en men kan het daarom nooit helemaal kennen. Daarom wordt 'een enorme nadruk' gelegd op het verzamelen en interpreteren van het 'toch al onvolledig' bronnenmateriaal. Tevens kan men een 'buitengewone eerbied' constateren voor 'zogenaamd oorspronkelijk onderzoek', waaronder men niet zozeer een 'uitgaan van oorspronkelijke ideeën' verstaat, als wel 'onderzoek, waarbij de individuele onderzoeker zich direct richt op de bronnen zelf, die oorsprong van alle kennis zijn'. Derhalve weigeren de meeste historici de bronnenstudie aan 'onderzoeksassistenten' over te laten en is teamwork 'een voor hen vies woord'. Individualisten als zij zijn voelen ze er evenmin voor om 'onderzoeksprocedures te normaliseren en te kanaliseren'. Vervolgens wijzen Diederiks en Wes (Landes en Tilly) op de grote ledenaanwas van de American Historical Association van 1957 tot 1968, namelijk 200\%. Zij zijn echter meer getroffen door 'aanwijzingen dat de expansie in het historisch bedrijf in de VS voorbij is en dat er zelfs een teruggang zal optreden'.

Von der Dunks verklaring van de rebellie tegen de geschiedenis (verzet tegen de status quo $^{7}$ en als van conjuncturele aard) achten zij niet voldoende. 'Een van de meest onthullende aspecten van de enquête van Landes en Tilly wijst namelijk in een andere richting'. Ter verduidelijking hiervan het volgende:

1) $33 \%$ van de geënquêteerde historici heeft zich in zijn opleiding intensief beziggehouden met althans één van de sociale wetenschappen; 2) $75 \%$ van de geënquêteerde historici is van mening dat tenminste één terrein van de sociale wetenschappen voor hun vak bijzonder belangrijk is; $66 \%$ gevoelt behoefte aan sociaal-wetenschappelijke bijscholing via een zomercursus en iets meer dan $50 \%$ zou een eventueel jaar studieverlof gebruiken om zich verder te verdiepen in een van de sociale wetenschappen. 'Vanuit deze gezichtshoek' onderscheiden Landes en Tilly 'drie soorten historici in de VS', nl. zij die geen enkele belangstelling hebben voor de sociale wetenschappen (vooral te vinden onder beoefenaren van ideeëngeschiedenis en de geschiedenis van de natuurwetenschappen), wier percentage zij op ca. 20 stellen; de 'geïnteresseerden' (vooral economisch-historici, die in contact staan met economisten), wier percentage 30 zou bedragen; en de 'gefrustreerden' (zij die

6. Dit is Carl Bridenbaugh's 'that Bitch-goddess QUANTIFICATION', in: 'The Great Mutation', American Historical Review, LXVIII (1963) 326 in de Leidse vertaling.

7. Zie noot 4 . 


\section{OFFRINGA}

weinig of geen kennis hebben van de sociale wetenschappen en ontdekten dat zij daardoor op essentiële punten als historicus tekortschoten), wier percentage 50 zou zijn.

'Het komt ons voor' - zeggen Diederiks en Wes - 'dat men op grond van deze cijfers niet zonder meer kan spreken van een crisis van voorbijgaande aard'. Zij signaleren echter in de VS aanzetten tot een structurele verandering van de geschiedbeoefening:

1) steeds meer wordt het onderwijs gericht op 'centrale onderwerpen, die niet aan tijd en plaats gebonden zijn'; de aankomende studenten zijn immers 'al te sophisticated' om nog warm te kunnen lopen voor 'versleten clichés' als 'de dageraad van de westerse beschaving' of 'het ontstaan van Europa'. 'De studenten willen het verleden benaderen in termen van politieke en sociale categoriën, waarmee zij via de sociale wetenschappen in contact komen. Zij willen op die manier komen tot algemene patronen van sociale verandering'; 2) er bestaat meer mogelijkheid om keuzevakken buiten 'het traditioneel domein van de geschiedenis' te nemen; 3) er worden meer en meer werkgroepen en colleges gegeven door teams van docenten uit 'andere vakgebieden'.

Onder het hoofdje 'tekortkomingen en kritiek' wijzen Diederiks en Wes erop dat, naarmate het heden opschuift kwantitatieve gegevens voor de historicus aan belang winnen. Als de historicus niet met statistiek, computer en modellen kan omgaan, laat hij zijn terrein aan anderen over.

In de huidige opleiding zijn zaken als methodologie, ontwerpen van onderzoeksprojecten, kwantitatieve methode en kennisnemen van theorieën van aanverwante disciplines vrijwel afwezig. Zelfs vanuit het oogpunt van de traditionele geschiedbeoefening laten de huidige praktijken in de opleidingen veel te wensen over.

Diederiks en Wes vermelden dan de volgende aanbevelingen van Landes en Tilly:

1) formulering van vraagstelling en opzetten van onderzoeksproject, oefening in logische bewijsvoering en keuze van onderzoekstechnieken dienen onder actieve medewerking der studenten expliciet en systematisch behandeld te worden; 2) de studenten moeten systematisch kennis maken met de sociale wetenschappen in zoverre deze relevant zijn voor de kennis van het verleden. Deze kennis kan zelf weer de ontwikkeling van nieuwe en het toetsen van bestaande sociale theorieën bevorderen; 3) de studenten moeten betrokken worden bij het verzamelen en interpreteren van bronnenmateriaal dat van waarde is voor problemen van sociaalwetenschappelijke aard, die in de traditionele geschiedschrijving verwaarloosd worden; 4) de keuzepakketten dienen in aanzienlijke mate samengesteld te worden op grond van 'themata en probleemstellingen' bijvoorbeeld oorlog, revolutie, macht, urbanisatie, agrarische samenleving en niet langer uitsluitend op grond van de traditionele geografische en chronologische indelingen; 5) de geschiedenis moet het belang erkennen van statistieken en computerprogramma's; 6) indien studenten zich willen verdiepen in multidisciplinaire problemen, bijvoorbeeld op het terrein van de sociale en economische geschiedenis, dan moeten zij voor de extra moeite besteed aan het zich eigen maken van bepaalde technieken, compensatie krijgen door vrijstelling van 'de traditioneel voorgeschreven stof'.

Ondanks de beschroomde wijze waarop Diederiks en Wes de Amerikanen door hun mond hebben laten spreken, reageerde Schöffer met nauw verholen irritatie en onverbloemde ironie op hun stuk. Begrijpelijk! Eerst Bertels en nu weer déze twee die in het nest van Fruin hun koekoeksei kwijt willen! Schöffer noemt zijn reactie 'Twee wegen naar het verleden' en bedoelt daarmee natuurlijk de door Landes en Tilly vastgestelde methodologische ideaaltypes: 'the social science mode' en 'the humanist mode'. Ik geloof echter 
dat de principiële betekenis van dit soort discussies beter uitkomt als we deze terminologie laten voor wat zij is en rustig constateren, dat het hier gaat om de oude tegenstelling tussen positivisme en historisme.

Aan de ene kant het in het Verlichtingsdenken wortelend positivisme met zijn groot vertrouwen in de rationaliteit en derhalve voorspelbaarheid van het menselijk gedrag; met zijn methodologisch uitgangspunt dat er slechts éen wetenschappelijke methode is, en wel die van de 'sciences'; en dat zich bij Comte openbaarde als 'sociologie', onder het motto: 'savoir pour prévoir afin de pourvoir'. Dit positivisme beoogde de maatschappelijke ontwikkeling te leiden op grond van kennis die de Engelse historicus Thomas Henry Buckle óók in het verleden zocht en voor de verkrijging waarvan hij, anders dan Comte, grote waarde hechtte aan de statistiek.

Daar dit positivisme, dat als ideaal had 'ordre et progrès', een vrucht was van de geweldige sociale spanningen van revolutie- en restauratietijd, is het geen wonder dat het in de jaren 1890 en volgende, ontdaan van zijn doctrinair vooruitgangsgeloof, weer terrein won, toen grote structurele veranderingen, met name het fenomeen der grote 'collectiviteiten' (groei van het grootbedrijf, trust- en kartelvorming, vakbeweging en politieke massapartij) en de groei van de grote stad, het klassieke liberale denken en het traditionele conservatisme voor onoplosbare problemen stelden.

In Frankrijk knoopte de socioloog Durkheim bij Comtes positivisme aan en liet de mens in zijn sociale bepaaldheid opgaan; in Duitsland trok Lamprecht met zijn pseudo-positivistische, collectivistische geschiedschrijving tegen de heersende historiografie van leer. Lamprechts revolutiepoging liep dood. Steunend op grondige vakkennis, konden zijn tegenstanders zijn vaak roekeloze hypothesen en generalisaties weerleggen, terwijl hij zelf nauwelijks enige theoretische en methodische steun vanuit het kamp der sociale wetenschappen hiertegenover kon stellen. Is het dan een wonder, dat vooral na de tweede Wereldoorlog de smeulende tweedracht in het historische kamp weer opgevlamd is? De overeenkomst tussen 1890 en volgende jaren en 1960 en volgende jaren is trouwens in meer dan één opzicht treffend: in beide decennia vond een onmiskenbaar neo-romantische, culturele revolte plaats. Maar wat ik hier wil vaststellen is dit: het gaat ook nu weer om de vraag of de geschiedenis al dan niet die van de grote collectiviteiten zal zijn. Naarmate nu de historicus zich steeds minder lid van een burgerlijke elite voelt die de toon aangeeft en waarbinnen hij op zijn beurt invloed kan uitoefenen (Ranke, Macaulay, Groen, Fruin, Gerretson, Geyl) zal hij in zijn groeiend gevoel van onmacht des te sterker de nadruk leggen op sociale factoren en als het ware een mystieke eenwording zoeken met sociale stromingen in zijn tijd die hem de illusie kan geven zijn vrijheid herwonnen te hebben.

En stel daar tegenover het historisme. Het gelooft in de zin der geschiedenis, maar die zin is slechts te ahnen; het rekent de mens tot het rijk der vrijheid (de cultuur) en acht hem een redelijk, zedelijk wezen ontheven aan de wetmatigheid van de natuur (het rijk der onvrijheid); het ziet volk en staat als de belangrijkste historisch gegroeide Gebilde die als zedelijke machten tot een hogere zijnsorde behoren. Binnen hun kader leeft de mens in de vrijheid, als hij zich gedraagt naar de waarden en normen die eigen zijn aan de fase van ontwikkeling waarin deze Gebilde zich bevinden: 'jede Epoche ist unmittelbar zu Gott'. Dit rijk der vrijheid - de geschiedenis - kan men niet erklaren, doch slechts versteken; hetgeen niet wil zeggen zwelgen in de kleurigheid van het verleden, maar een door voortdurend reflecteren vooruitschuiven van de grens van onze kennis.

Dit was de - soms in pseudoreligie ontaarde - geschiedschrijving van het Bildungsbürgertum, waarvoor het vanzelfsprekend was, dat - ik citeer Diederiks en Wes - de geschiedenis 'een algemeen aanvaard element in de cultuur van onze samenleving' is. In deze burgerlijke 


\section{OFFRINGA}

cultuur gold het woord van Burckhardt dat Van der Pot in zijn bijdrage met kennelijke instemming aanhaalt: 'Was einst Jubel und Jammer war muss nun Erkenntnis werden . .. Wir wollen durch Erfahrung nicht sowohl klug (für ein andermal) als weise (für immer) werden'. Oók om de tegenstelling tussen het pragmatische 'klug für ein andermal', dat op direct nut voor het heden uit is, en het 'weise für immer', dat óók inhoudt het levend houden van het cultuurbezit, gaat het nog steeds! En ik maak mij sterk dat de botsing van wereldbeschouwelijke aard, die zich daarin uitdrukt, in hoge mate de emotionaliteit van de discussie verklaart. Na aldus de sociale context van de 'klassieke' geschiedschrijving in herinnering gebracht te hebben, wil ik er met nadruk op wijzen, dat haar 'burgerlijke' afkomst haar evenmin diskwalificeert als onvervreemdbaar erfgoed, als die van andere verworvenheden.

Het historisme is trouwens steeds verder uit hoge sferen afgedaald. Als geschiedbeschouwing heeft het in het marxisme een zeer aardse gedaante aangenomen, maar ook in die leer heeft het zijn kern, een diep besef van de historiciteit van het menselijk bestaan, niet prijsgegeven. Als methode is het - nauw verbonden met de filologisch-kritische tekstanalyse, maar daarmee zeker niet meer identiek - nog steeds de weg die iedere historicus - door 'verstehen' - moet gaan, als hij het menselijk bestaan in zijn telkens anders zijn wil 'kennen'. Dit geldt ook voor de historicus die zijn aandacht richt op aspecten die in tabel, grafiek of statistiek zijn vastgelegd.

Maar nu terug naar Schöffer. Wat voert hij tegen het stuk van Diederiks en Wes (Landes en Tilly) aan? Hij stelt de methodenstrijd centraal en plaatst tegenover elkaar de methode die uitgaat van 'de conceptie' en daaraan de gegevens toetst, en de methode waarvoor 'de descriptie' essentieel is 'en welke', zoals Bertels dat formuleert, 'op grond van de gegevens tracht te komen tot reconstructie van een daartoe uit het verleden afgeperkt onderwerp'. Schöffer stelt echter dat de samenhang tussen beide methodes 'van zeer wezenlijke betekenis is', niet alleen omdat beide op de bronnen steunen en daarmee op 'de zo verfijnde en verbeterde techniek van de historische bronnenkritiek' maar ook omdat vele 'conceptuele' historici al gauw naar beschrijving verglijden wanneer hun model onbruikbaar blijkt, en omgekeerd 'vele 'descriptieve' historici haast ondanks zichzelf uitgaan van vooronderstellingen en er dan ook maar goed aan zouden doen deze expliciet te maken'. Zijn conclusie dat de toetsing van model en conceptie nooit kan slagen zonder descriptieve reconstructie, en descriptie nooit 'interessant' kan worden zonder hypotheses, licht hij dan vervolgens toe door kritiek op Tilly's, uit 1964 daterend, boek over The Vendee. A Sociological Analysis of the Counterrevolution of 1793, waarin deze een model van urbanisatie toetst, maar bewust het tijdselement uitsluit, waardoor 'een merkwaardig statisch beeld' van de opstand ontstaat. De wijze, waarop Tilly zich tegen 'de oudere geschiedenis' afzet 'bedroeft' Schöffer 'een beetje', omdat dit statische effect juist zijn oorzaak heeft in de afwezigheid van 'descriptie'.

Vervolgens komt hij dan met aanbevelingen voor verbeteringen van het opleidingsprogramma:

1) meer plaats voor bronnenkritiek en technieken van 'de kritisch-filologische methode';

2) vooral aandacht voor de descriptieve reconstructie, waartoe hij onder meer rekent 'de aanscherping van het tijdsbesef, waarbij onvermijdelijk traditionele overzichten van de geschiedenis van eigen cultuurkring als fond voor verder onderzoek zullen moeten gekend worden'; aandacht ook voor de plaats van het object in 'eigen tijd en groep, met de poging ook om 'Verstehen' te wekken. Daarin besloten ligt tevens het besef en inzicht van de veranderingen in tijd- en groepsgelaagdheid'; 3) training in het schrijven, de compositie 
van een betoog en de wijze van bewijsvoering met alle daarbij behorende spelregels ${ }^{8}$. $\mathrm{Na}$ wat ik hiervóór in verband met het historisme opgemerkt heb, zal het duidelijk zijn dat ik Schöffers wensen van harte ondersteun. Dat neemt echter niet weg, dat ik het, gezien zijn standpunt dat beide methodes in samenhang toegepast moeten worden, inconsekwent acht dat hij blijkbaar niet bereid is om in de opleiding aandacht te besteden aan de theoretische en methodologische vorming die zijn Leidse vakgenoten nodig achten. Ik zal verderop in mijn betoog op deze kwestie dieper ingaan.

Op dit punt aangeland zou ik mijn 'evaluatie' van beide posities begonnen zijn, als de filologisch-kritische component van mijn historisch geweten mij niet aangespoord had om, met alle waardering voor de voorlichtingsarbeid van Diederiks en Wes, naast de authentieke Schöffer-tekst ook het boekje van Landes en Tilly weer eens ter hand te nemen. De herlezing ervan heeft mij verrast. Niet omdat de inhoud zo sensationeel zou zijn - van de eerdere lectuur was mij niets bijgebleven -, maar omdat mij bleek dat de problemen die Landes en Tilly signaleren in een context thuis horen, die in het te sterk simplificerende stuk van Diederiks en Wes niet zichtbaar wordt.

Kortheidshalve vat ik mijn op- en aanmerkingen puntsgewijs als volgt samen:

1) het Amerikaanse onderzoek was zeer bewust sterk selectief. Overeenkomstig de 'terms of inquiry' en met het oog op 'its objectives' (te weten: het ontwerpen van een 'national policy' voor de social sciences, waaronder ook 'history as a social science' en 'psychiatry as a behavioral science') werd de enquête gehouden onder diegenen 'within and without the historical profession, who are in whole or in part engaged in work of a social science character and with that part of historical study and training that falls within the scope of social science'. 'This focus' - aldus Landes en Tilly - 'has no invidious implications', omdat geschiedenis nu eenmaal geen 'unitary discipline' is en de verschillende soorten historici elkaar nodig hebben ${ }^{9}$. Ja, juist zij die werken met sociaal-wetenschappelijke technieken behoren de 'humanistic approach to historical knowledge' te kennen en te appreciëren. 'We cannot afford to gain a world of numbers and models and lose our historical souls in the process ${ }^{10}$. Landes en Tilly zien het onderscheid tussen de 'social science' en 'humanist' benadering derhalve als een 'heuristic device': het gaat hier om ideaaltypes, want vele, zo niet alle historici beschouwen zichzelf 'as both humanists and social scientists'. Mijn conclusie: als er frustaties bij deze enquête geconstateerd zijn, dan moeten die gezocht worden bij diegenen (het gaat hier niet alleen om historici van opleiding) die zich met specifiek 'social-scientific' ${ }^{\prime 1}$ historisch onderzoek bezighouden;

8. Terecht protesteert Schöffer, tegen de opmerkingen van Diederiks en Wes, dat de historicus er de voorkeur aan geeft alles 'mooi te verpakken in literair verzorgd proza'. Dit is trouwens een milde weergave van wat Landes en Tilly beweren: 'His (i.e. the historian's, Offr.) primary concern remains the story, and he prefers to weave his assumptions and interpretations into the account in such a way as not to detract from its fluency and interest. In general, he prizes subtlety more than precision' (Landes en Tilly, History, II). Subtiliteit contra nauwkeurigheid]

Schöffer daarentegen betoogt: 'vormgeving in taal, - dat wil zeggen compositie, stijl, woordkeuze -, is niet alleen essentieel, omdat hierdoor gedachtenwisseling tussen vakgenoten mogelijk wordt en de culturele functie van geschiedschrijving in de maatschappij kan worden vervuld, maar ook voor het onderzoek- en denkproces van de historicus zelf. Langs de weg van schriftelijke vormgeving wordt hij gedwongen eigen denkbeelden te ordenen, bewijsvoering te verharden en heldere overdracht van gegevens te verwezenlijken. Gelukt dat alles, dan wordt zulk een stuk geschiedschrijving een soort 'kunstwerk', n'en déplaise het feit, dat de vakhistoricus gewoonlijk (helaas) geen begaafd kunstenaar is'.

9. Landes en Tilly, History, 1.

10. Ibidem, 2.

11. Meer dan mijzelf lief is zal ik een dergelijke terminologie onvertaald laten. 


\section{OFFRINGA}

2) de oorzaken van deze frustraties zijn in hoge mate van zeer praktische aard. Vergeleken met de andere 'social sciences' is geschiedenis een 'poor relation'. Historici krijgen minder geld, hebben een zwaardere onderwijstaak en zuchten onder zware administratieve besognes. Vooral zij die zich met de geschiedenis van de VS en West-Europa bezighouden hebben het moeilijk. Zij die zich in een 'area' (Latijns-Amerika, het Verre Oosten, Rusland enz.) gespecialiseerd hebben zijn meestal aan instituten verbonden die ruime subsidies genieten. Hier is meestal sprake van onderzoek in een ruimer sociaal-wetenschappelijk kader. Nauwe banden met andere sociale wetenschappen betekent: meer geld, minder onderwijs, meer onderlinge wetenschappelijke steun, dus minder frustraties.

Landes en Tilly stellen echter de methodieken - in de eerste plaats de kwantitatieve - zodanig centraal, dat men zich gaat afvragen of de inwoning in het huis der geschiedenis waarom ook zij heel hoffelijk verzoeken niet spoedig zou uitdraaien op het vertrek van de oude bewoners. Ik heb hierboven reeds gesteld, dat een vruchtbare discussie over methodische kwesties niet gevoerd kan worden zonder dat men in wijsgerig opzicht een standpunt inneemt. Niet zonder betekenis is het dan ook dat Landes en Tilly zelf toegeven, dat zij klassieke vragen als die naar het bestaan van een specifieke historische kennis op grond van het 'verstehen' nauwelijks aangeroerd hebben: zij richtten immers hun aandacht bijna uitsluitend op 'the social-scientific sector, loosely defined'.

De Amerikaans-Amsterdamse socioloog Alvin Gouldner wijst er echter op, dat ook methodologie als ideologie kan fungeren en haalt daarvan als voorbeeld Charles Tilly aan, op wiens nationale 'social accounting system' hij het volgende commentaar geeft:

To the degree that the social sciences are modelled on the physical sciences, they entail the domain assumption that people are 'things' which may be treated and controlled in much the same marmer that other sciences control their non-human materials; $\ldots{ }^{12}$.

Methodologie is niet slechts een 'purely technical concern', maar veel meer dan dat: 'for it is commonly infused with ideologically resonant assumptions about what the social world is, who the sociologist is, and what the nature of the relation between them is ${ }^{13}$. Vanuit dit gezichtspunt gezien is dunkt mij de term 'humanistische' geschiedschrijving wel zéér gelukkig gekozen!

Ondanks hun betuiging van het tegendeel en - nota bene! - het feit dat de Amerikaanse enquête 'social-scientific historians' betreft, doe ik Landes en Tilly geen onrecht, als ik op grond van wat zij verspreid in hun boekje over aard en object van de geschiedwetenschap opmerken, vaststel dat zij de geschiedenis in de eerste plaats zien als een 'ancilla sociologiae' (sociologie staat hier voor 'de overige sociale wetenschappen') en derhalve ervan uitgaan dat zij zich haar vraagstelling en methodieken door deze 'social sciences' moet laten voorschrijven. Want, wat onderscheidt de bijdrage van de geschiedenis van die van de andere sociale wetenschappen aan de 'knowledge of man'? Antwoord: 'Perspective'. 'This is no small matter', zeggen Landes en Tilly ${ }^{14}$. Neen, maar ook niet voldoende om de geschiedenis de status van zelfstandige discipline toe te kennen!

Maar daarnaar gaan hun gedachten dan ook niet uit, want hun historicus zal trachten 'to derive generalizations that will fit into the larger corpus of social and behavioral sciences $^{15}$; en daarom zal met name de 'historian as social scientist' 'selfconciously'

12. Alvin W. Gouldner, The Coming Crisis of Western Sociology (Londen, 1971) 49-50.

13. Ibidem, 51.

14. Landes en Tilly, History, 6.

15. Ibidem.10. 
streven naar 'methodological rigor'. Welnu, kwantitatief werk belichaamt - aldus Landes en Tilly - beter dan welke andere soort geschiedenis de pretenties en aspiraties van de historicus als 'social scientist' ${ }^{16}$. Vandaar dat het werk van Soboul, Cobb, Hobsbawn, Rudé c.s. methodologisch tot het klassieke type geschiedenis gerekend moet worden: de volgende stap moet zijn het verzamelen van 'case-studies' die zich voor een statistische bewerking lenen. De vernieuwing door Soboul c.s. ligt 'in new questions asked, sometimes of new sources drawn from a variety of contexts to permit comparison'. Hun interpretatie is primair kwalitatief ${ }^{17}$.

Dat deze voorkeur voor de kwantitatieve methode inderdaad verre van waardevrij is en kan leiden tot een meestal onuitgesproken visie op de dynamiek van historische processen, blijkt uit een passage, waarin Landes en Tilly over het actuele belang van de historische demografie spreken en wel in verband met de toepassing van geboortebeperking in Frankrijk in de achttiende eeuw:

Because of the precocity of this adaptation, France, which in the seventeenth and eighteenth centuries was far away the most populous and powerful nation in Europe, never shared in the population explosion of the industrial period and [curs. Offr.] lost forever the political preeminence she had enjoyed under Louis XIV and Napoleon ${ }^{18}$.

Welke zijn de kenmerken van 'social-scientific history'19 ? Zij streeft naar 'collective history, that is history directly linking the recorded experiences of large numbers of persons or social units to patterns of behavior or change'; zij tracht die gedragspatronen in termen van theoretische concepties en modellen te begrijpen; zij steunt vooral op de comparatieve methode, waaronder niet verstaan moet worden 'the pro-forma laying of parallel experiences side by side', maar een systematische analyse van gelijksoortige processen 'in different settings in order to develop and test general ideas of how those processes or phenomena work'. Wie Nederlandse vakgenoten, wier werkwijze verwant is aan de door Landes en Tilly voorgestane, beluistert, weet dat ook zij in grote onvrede leven met 'de' geschiedenis en in feite slechts deze collectivistische geschiedschrijving wetenschappelijk aanvaardbaar achten. Trouwens, ook expliciet stellen Landes en Tilly dat óók de gewone historicus zich vertrouwd moet maken met theorie, computertechnieken, modelbouw enz., omdat met name de contemporaine geschiedenis 'the real measurement' steeds ziet groeien en waar cijfers ontbreken, 'surveys' die zullen creëren ${ }^{20}$. Als de historicus deze 'hardest evidence' aan de sociologen overlaat, wat zal er dan van de geschiedenis overblijven? 'A truncated residue?' Dat gevaar bestaat inderdaad; echter - zo meen ik - niet alleen als men deze 'evidence' buitensluit en in verband daarmee nieuwe vraagstellingen aan outsiders overlaat, maar vooral ook als men deze middelpuntvliedende tendenties naar 'sociologiserende' historische deeldisciplines toeleidt en uit het oog verliest, dat de geschiedenis in een eigen specifieke problematiek een zwaartepunt heeft. Want de geschiedenis heeft wel degelijk een niet afgeleide taak: zij moet streven naar wat Huizinga heeft genoemd een beeld van het verleden, maar wat ik liever met zijn leerling Romein wat aardser, wat sociologischer, wil noemen een integrale geschiedenis. Landes en Tilly besef-

16. Ibidem, 14 .

17. Ibidem, 43-44.

18. Ibidem, 59.

19. Ibidem, $71 \mathrm{vlg}$.

20. Ibidem, 74 . 


\section{OFFRINGA}

fen heel goed, dat zo'n opvatting der geschiedenis methodologische consequenties heeft: opmerkingen over 'history as art' en over de tegenzin waarmee de historicus zijn confrontatie met de bronnen aan anderen overlaat, laten zij overgaan in de volgende passage:

These values have, to be sure, a strong intellectual justification. In so far as history attempts to see things whole, it is, more than other disciplines, dependent on individual perceptions. Interpretation and understanding are never routine; there are too many variables to reduce the analysis to some kind of procedure ${ }^{21}$.

Mijn conclusie: de discussie over de crisis in de geschiedwetenschap moet niet gevoerd worden vanuit de vraag naar de juiste methodieken, maar men moet zich allereerst afvragen: wat is haar object, wat is haar functie.

Bij dit streven 'to see things whole' kan men evenmin buiten de inzichten verkregen door een collectivistische benadering als buiten die welke een individualiserende aanpak oplevert. Sociologische benadering betekent abstraheren, betekent het vaststellen van fenomenen die bestaan bij de gratie van deelaspecten van individueel menselijk gedrag. Hoe regelmatiger, hoe meer voorspelbaar dit gedrag, des te beter acht de socioloog zijn onderzoek geslaagd. De mens als individu èn als speler van diverse, soms conflicterende sociale rollen zorgt er echter voor dat zich in historische situaties een configuratie van sociale en individuele factoren doet gelden, waarbinnen de voorspelbaarheid van het menselijk gedrag zeer kan variëren, ja, zelfs zo gering kan zijn dat erkende sociologische regelmatigheden gefalsifieerd worden. Het is de taak van de historicus al deze factoren, waaronder 'de Grote Man' als 'Weichensteller' (aldus Weber) kan fungeren, te identificeren en hun onderlinge relaties vast te stellen, ten einde tot een integraal beeld te komen. Dat naarmate het historisch perspectief dieper is, de voorspelbaarheid van ontwikkelingen aan waarschijnlijkheid wint, is evident. Maar evenzeer waar is, dat tendenties, van hoe groot gewicht zij ook mogen zijn, binnen een unieke situatie kunnen afbreken of omgebogen worden; en voorts: dat, ook al zou een bepaalde tendentie het 'beeld' gaan bepalen, wij als historicus de voorafgaande 'situaties' niet mogen mediatiseren, omdat zij door de tijdgenoot op specifieke wijze zijn beleefd.

De sociologie isoleert; de geschiedenis integreert. De socioloog wil weten wat onder die en die omstandigheden zal gebeuren en acht zich daarom instrument voor 'policy makers', de historicus is ook niet vies van deze wetenschap, maar laat in de eerste plaats zien wat er zoal kan gebeuren. De historie maakt ons dus niet zozeer 'klug für ein andermal' als wel 'weise für immer': zij geeft minder zekerheden dan mogelijkheden, welke laatste echter niet minder fundamenteel behoeven te zijn dan de eerste, die wij trouwens misschien beter onmogelijkheden kunnen noemen. De geschiedenis biedt de mogelijkheid tot oriëntatie door 'verstehen'. Ook door déze historische ervaring kunnen we van het verleden leren.

Het zal duidelijk zijn, dat ik integrale geschiedenis opvat als sociale geschiedenis in ruime zin (en niet 'with politics left out'); en tevens dat ik de historische 'deeldisciplines' (economische, sociale en kerkgeschiedenis enz.) als evenzovele transmissiebanden zie, door middel waarvan geschiedenis en systematische wetenschappen elkaar wezenlijk kunnen verrijken.

De actualiteit en vooral ook de verstrekkende practische betekenis van al deze problemen in hun samenhang kan niet beter gedemonstreerd worden dan door in te gaan op een verslag dat drs J. R. Soetenhorst in de NRC van 8 november 1973 onder het hoofd 'Historici

\section{Ibidem, 21.}


moeten meekunnen in de maatschappelijke slag' uitbracht van een gesprek met de Rotterdamse hoogleraren $\mathrm{H}$. van den Brink en P. W. Klein, de eerste verbonden als rechtshistoricus aan de juridische faculteit, de tweede als economisch historicus aan de economische faculteit. Beide heren hebben met de historicus D. J. Roorda, destijds lector in de sociale geschiedenis aan de sociale faculteit in Rotterdam, nu hoogleraar in de algemene geschiedenis te Leiden, een plan opgesteld voor een Rotterdamse subfaculteit geschiedenis, waar - aldus de desbetreffende nota - een historicus gevormd zal worden, waarvan men mag verwachten dat hij door vertrouwdheid 'met de systematiek van maatschappijwetenschappen als recht, economie en sociologie' meer dan tot dusver mogelijk was, oog zal hebben voor 'de maatschappelijke regelmatigheden of wetmatigheden, welke mede de loop van het historische gebeuren bepalen'.

Men wil - aldus nog steeds het verslag in de $N R C$ - 'een maatschappij-geschiedenis, een etiket dat boven rechts-, sociale en economische historie uitgaat ${ }^{22}$. Van den Brink voegt daar ter verduidelijking nog aan toe: 'Wij willen niet aansluiten bij de literair-filologische traditie, waarop de meeste Nederlandse geschiedenisstudies stoelen'. Op 'de klemmende vraag naar de toekomst' van abituriënten van zo'n nieuwe maatschappijhistorische opleiding antwoordde Klein dat hij nieuwe mogelijkheden zag: 'Bijvoorbeeld in beleidsfuncties bij nationale en internationale organisaties en in het bedrijfsleven'. Want:

Actuele problemen ontstaan niet in het luchtledig: er is geschiedenis. Een voorbeeld: ontwikkelingseconomen zijn in principe pure technici, zonder historische kennis van [de?, Offr.] ontwikkelingslanden waar zij heen gaan. De historicus die is opgeleid in maatschappijwetenschappen kan relaties leggen voor vakspecialisten.

En dan weer de $N R C$ :'Van den Brink en Klein sluiten in hun ideeën over de geschiedenis duidelijk aan bij de maatschappelijke actualiteit en relevantie. Klein: 'Het gaat mij niet om de kennis van het verleden om der wille van dat verleden'. Zover wil zijn rechtshistorische college echter niet gaan: 'Ik ga' - en dat is misschien een klein verschilletje met Klein - 'niet zover dat ik met het materiaal uit het verleden iets in het heden wil doen ...'. Maar 'Klein': fel betogend: 'Waarom wil ik de maatschappij van vroeger leren kennen? Om er iets mee te kunnen doen, om achterliggende gedachten aan te vechten of te steunen ... Voor mij moet de geschiedwetenschap 'vermaatschappelijkt' worden'. De heren ontmoeten elkaar echter weer in hun verbazing over 'de onsystematische opleiding van historici in Nederland' en zeggen zich duidelijk geïnspireerd te voelen door de structureel gerichte geschiedbeoefening in Frankrijk. En dan laat Klein de aap uit de mouw: de studenten zien geen patroon in hun opleiding,

omdat de vakjes losstaan van elkaar. Denk maar eens aan de benamingen van de leerstoelen : vaderlandse geschiedenis, algemene geschiedenis. Zijn dat studieobjecten? Zo'n leerstoel behoeft niet te verdwijnen, maar het is te eenzijdig om een studieprogramma op te bouwen...

Waar Landes, doortrokken als zijn denken is van de cultuur van zijn vak, steeds weer zijn ijver de teugels aanlegt, draaft Klein ongeremd op het doel af: de ontbinding van de geschiedenis in 'vakjes' ${ }^{23}$ volgens het plan: een economisch-historische, een sociaal-histo-

22. Er zouden drie studierichtingen moeten komen: de economisch-historische richting, de sociaal-historische richting en de rechts-historische richting.

23. Een dergelijke opsplitsing gaat rechtstreeks in tegen de geest van de groep rond de Annales, 


\section{OFFRINGA}

rische, en een rechtshistorische richting; maar - zegt Klein - er valt ook nog te denken aan medische en technische geschiedenis, dat wil zeggen historische aspectwetenschappen die min of meer in combinatie met elkaar aan andere sociale wetenschappen vastgekoppeld worden ten einde variëteiten 'maatschappijgeschiedenis' te krijgen, 'om er iets mee te doen'.

Ik vind het Rotterdamse plan als knuppel in het wat conservatieve historische hoenderhok heilzaam; ik vind de strekking ervan verwerpelijk, omdat het de neiging van egocentrische (of imperialistische) specialisten om hun belangstellingssfeer te verabsoluteren versterkt en - wat veel erger is - op het uiteenvallen van de geschiedwetenschap in aan corresponderende systeemwetenschappen ondergeschikte onzelfstandige vakjes anticipeert.

Dat 'algemene geschiedenis' geen studieobject is, zal niemand Klein bestrijden. Maar als Leids docent weet hij toch dat sinds Fruin de vaderlandse geschiedenis de harde kern van de geschiedenis opleiding is geweest en dat sinds de dood van Huizinga en Colenbrander ook in Leiden de 'algemene geschiedenis' - de 'restgeschiedenis' - naar tijdvak en 'area' opgedeeld wordt? De vaderlandse geschiedenis (een prachtobject voor area study!) is een zinvol kader waarbinnen men op de meest geavanceerde wijze structurele geschiedenis kan beoefenen. Hetzelfde geldt ook voor de studie van periodes. Als Klein zou zeggen dat de huidige indeling daarin gebrekkig, want historisch gegroeid is, zou ik daar van harte mee instemmen. Maar dat bewijst slechts dat de geschiedenis zich meer dan tot dusver moet richten op één van haar specifieke problemen, de periodisering, hetgeen men aan geen der deeldisciplines kan overlaten, tenzij men reeds bij voorbaat voor een monocausale (bijvoorbeeld een economistische) verklaring van de historische ontwikkeling gekozen heeft. De verkaveling van de geschiedenis in richtingen 'maatschappijgeschiedenis' die zich oriënteren aan een systematische discipline, betekent dat specifieke bijdragen van het historische denken zullen verschralen, waarbij ik tevens erop wijs dat de geschiedenis slechts haar functie als 'een algemeen aanvaard element in de cultuur' (Diederiks en Wes) kan vervullen, als zij als integrale geschiedenis deze historisch-wetenschappelijke activiteiten richting geeft.

In ieder geval is één ding duidelijk: als er Nederlandse historici zijn die zich in het Amerikaanse rapport zullen herkennen, dan zijn dat 'social-scientific historians' als Diederiks en Wes die zich terecht willen oriënteren op - globaal gesproken - 'de sociale faculteit' omdat zij de wetenschappelijke en materiële steun die zij niet kunnen missen in de eigen vakkring niet in voldoende mate vinden; en mèt hen de Rotterdamse heren die, zoals zij zelf zeggen, geisoleerd staan in hun faculteiten, naar ik aanneem omdat men daar onvoldoende oog heeft voor wat de geschiedenis aan het denken over 'mens en maatschappij' kan bijdragen.

Een opvallend feit nu is, dat de historici, vaak als gevolg van evidente onwetendheid omtrent de problemen van hun collega's der 'social sciences' tegenover het machtsvertoon van die kant sinds het einde van de Tweede Wereldoorlog merkwaardig defensief staan. Zelden stellen zij vragen als: hebben jullie nu werkelijk een algemeen aanvaard corpus van theoretische kennis die ons ook nieuwe inzichten in historische structuren en processen kan geven?; en: in hoeverre kunnen jullie op grond van theorie en research bijdragen tot de beleidsvorming door overheid en bedrijfsleven ${ }^{24}$ ? Wat die eerste vraag betreft dit: de de sociologen - ik bepaal me tot hen, omdat de relatie van ons vak tot de sociologie van principiëler betekenis is dan die tot bijvoorbeeld de economische wetenschap - hebben

waarop de Rotterdammers zich beroepen. Febvre c.s. staan een integrale geschiedenis voor die onder de sociale wetenschappen de plaats van eerste onder de gelijken behoort in te nemen.

24. Ik spreek hier niet over de meest exacte der sociale wetenschappen, de economie, die trouwens het minst de geschiedenis nodig heeft. 
zich als studieobject gekozen de min of meer stabiele structuren en processen van sociale $\operatorname{aard}^{25}$. Ofschoon het al verdienstelijk is, dat zij ettelijke structuren en processen hebben blootgelegd, blijven ze als 'scientists' niet bij descriptie staan maar trachten tot opstelling van structuur- en bewegingswetten te komen. Welnu, waarvan de vaak slecht geïnformeerde (inderdaad!) historicus geen notie heeft, dat is het feit dat als het op het opstellen van een balans van al dat theoretiseren aankomt, dè sociologische theorie een bundel van al dan niet met elkaar in overeenstemming te brengen theoretische gezichtspunten blijkt te zijn. Zo leidt bijvoorbeeld het uitstekende handboek van Walter L. Wallace Sociological Theory in tot

eleven (plus one 'missing link') current, influential, and explicitly formulated theoretic viewpoints in sociology. It therefore describes current thinking regarding 'what is to be observed' in any given future sociological investigation and regarding 'the form in which the results' of such an investigation may be expressed ${ }^{26}$.

Die elf 'theorieën' zijn dan: ecologisme, demografisme, materialisme, psychologisme, technologisme, functioneel structuralisme, ruil structuralisme, conflict structuralisme, symbolisch interactionisme en functioneel imperativisme, aan welke 'ismen' de illustere namen van onder anderen Parsons, Merton, Homans, Ogburn, Blau, Dahrendorf en Marx verbonden zijn. Een historicus die van zo'n theorie kennis neemt zal vaak in de ban van het betoog raken, geimponeerd zijn door de consistentie ervan, maar als hij al die embarras $d u$ choix heeft kunnen overwinnen zal hij eerder ontdekken dat zijn historische gegevens zijn uitverkoren theorie bevestigen, dan dat omgekeerd deze hem inzichten in specifieke historische situaties verschaft die hij anders niet verworven zou hebben. Wil dit zeggen dat hij dus geen kennis moet nemen van dè sociologie? Integendeel, want deze scherpt zijn blik voor sociale fenomenen en verschaft hem het begrippenapparaat dat hem in staat stelt daarover exact te denken en te schrijven. Geen geringe winst!

Maar hoe staat het nu met de hiervoor gestelde vraag naar het nut van de sociologie voor de vorming van beleid? Ik maak mij sterk dat niet alleen de historicus op de aangegeven wijze van de theorie profiteert. Ook de sociale onderzoeker zal langs deze weg de hem toegewezen sector van de sociale realiteit benaderen. Zijn bijdrage tot de oplossing van problemen van macro- en microsociologische aard ligt in de eerste plaats in het feit dat hij - geleid door theoretisch inzicht en vooral gebruik makend van kwantitatieve methodieken!-een contemporaine realiteit doorzichtiger maakt. Maar ook al zal de socioloog, indien gevraagd, beleidsvoorstellen doen, toch zullen de 'policymakers' - althans dit hebben mij sociologen menigmaal verzekerd - de research resultaten in de eerste plaats gebruiken ter oriëntatie in de materie, inzake waarvan zij beslissingen moeten nemen. Met andere woorden: het sociologisch rapport is in principe op geen andere wijze 'nuttig' voor bijvoorbeeld de oplossing van problemen die voortvloeien uit de noodzaak de gemeentelijke indeling in een provincie te wijzigen, dan de historische analyse voor een ander doel. Maar al zal in het rapport de nadruk liggen op de volledigheid van de voor de opdracht relevante gegevens, toch kan - de vaak zeer simpele historische inleidinkjes bewijzen dat-het historisch perspectief niet gemist worden: ter verklaring van de taaiheid van attitudes en structuren.

Terecht betogen Van den Brink c.s. dat men maatschappelijke problemen in een historisch

25. Aldus J. A. A. van Doorn en C. J. Lammers in hun Moderne sociologie (Utrecht, 1959) 24.

26. Walter L. Wallace, Sociological Theory. An Introduction (Londen, 1969) X-xi. 


\section{OFFRINGA}

perspectief moet zien. Ik neem zelfs aan dat zij dit perspectief zelfs verder naar het verleden willen verlengen dan hun collega's van de respectievelijke systematische wetenschappen nu al in theorie zijn bereid te doen, maar dat is een opvatting, die eerst nu, nu er indicaties zijn dat de sociologie zelf in een crisis geraakt, langzamerhand veld wint. Het geweldig optimisme, waarmee men na 1945 aan de slag ging met het doel op grond van een waardevrije sociale wetenschap door middel van 'social engineering' bij te dragen tot hervorming van de maatschappij, is in deceptie geëindigd. De vrij jonge wetenschap kon de te hoge verwachtingen niet honoreren. De sociologen bezinnen zich nu op hun vak en gaan inzien dat hun diverse theorieën, verre van waardevrij te zijn, berusten op impliciete premissen en zelf vrucht van sociale situaties zijn. Zij wenden zich tot klassieken van het vak: Tocqueville, Marx, Durkheim, Simmel, Weber, maar distantiëren zich niet zelden van de grootmeester van deze tijd, Talcot Parsons.

Dat de historiciteit van de sociale realiteit van dit proces van herwaardering in toenemende mate ook bij de theorievorming erkenning zal vinden, blijft een voorspelling, maar ik waag haar te doen. Ik ben dan ook van mening, dat er geen behoefte is aan het hybridische wezen 'maatschappijhistoricus', dat noch historicus noch socioloog enz. zou zijn. Wat de maatschappij nodig heeft zijn ten eerste sociologen, juristen, economisten die historisch hebben leren denken, niet omdat men uit het verleden iets kan leren ${ }^{27}$, maar omdat hun eigen theoretici tot het inzicht gekomen zijn, dat hun wetenschap niet ahistorisch kan zijn; ten tweede - maar niet op de tweede plaats! - historici die hun vak als integrale (structurele, sociale) geschiedenis beoefenen; ten derde specialisten in de deelaspecten der geschiedenis (bijvoorbeeld economische geschiedenis, sociale geschiedenis als geschiedenis van sociale groepen en hun onderlinge relaties enz.), wier opleiding de gezamenlijke taak moet zijn van de historische vakgroep (subfaculteit) en van de desbetreffende systematische wetenschap. Het Rotterdamse plan voor een subfaculteit maatschappijgeschiedenis komt er mede op neer dat men zich neerlegt bij het feit dat zowel de opleiding van sociologen als die van historici te wensen overlaat.

Dat de geschiedenisopleiding ernstige gebreken vertoont, is ook mijn vaste overtuiging. Maar men zal begrepen hebben, dat die overtuiging gegroeid is vanuit een visie die meer overeenkomt met die van Schöffer dan met de ideeën van Landes en Tilly (Diederiks en Wes), waarin mijns inziens een tendentie besloten ligt die wijst naar de 'ontbinding in factoren' die de Rotterdammers ons voor ogen getoverd hebben. Juist daarom echter vind ik Schöffers voorstellen voor verbetering van de opleiding te uitsluitend gericht op consolidatie van het beproefde. Mijns inziens hebben alle studenten evenzeer een zorgvuldig doordachte inleiding tot sociaalwetenschappelijk denken nodig. Zij moeten vertrouwd zijn met de belangrijkste begrippen en theorieën uit de sociologie en politicologie en vooral ook zodanig wegwijs gemaakt worden, dat zij zelf in staat zijn voor werkcollege en scriptie de ter zake doende sociaalwetenschappelijke literatuur op te sporen. Een scriptie over bijvoorbeeld nationalisme die uitmunt door onbekendheid met wat de 'social scientists' hierover geschreven hebben, moet een onmogelijkheid worden. Het verleden leert men immers evenzeer kennen door kennis van het heden, als het omgekeerde het geval is. Wil men daarom het historisch besef verfijnen, dan moet ons denken over

27. Klein: 'Natuurlijk geeft de geschiedenis geen pasklaar recept hoe je nu problemen moet aanpakken. Maar een studie over bureaucratie in de loop der eeuwen of over het begrip 'welvaart' onthult toch iets, waar je nu je voordeel mee kunt doen'. Ongetwijfeld. Maar ik zie al de spotlichtjes in de ogen van 'sociale wetenschappers', zo niet een sarcastische plooi om hun lippen, als een 'gewoon' historicus het zou wagen dit als antwoord te geven op hun pertinente vraag naar het nut van zijn wetenschap! 
sociale fenomenen goed geschoold zijn. Royale toelating van de sociale wetenschappen op ons vakterrein, zal tevens duidelijk maken dat hun waarde onmiskenbaar, maar tevens zéér betrekkelijk is. De onvrede die met name studenten aan de dag leggen over het ontbreken van enige sociaal-wetenschappelijke vorming - voor een niet gering gedeelte toe te schrijven aan de overspannen verwachtingen die men daarvan heeft - zal pas verdwijnen, wanneer zij zelf mogelijkheden en grenzen daarvan hebben leren kennen. Ik neem aan, dat een dergelijke duidelijkheid de docenten niet minder goed zal doen. Blijft men de boot afhouden, dan zullen economische en sociale geschiedenis de rol van 'alternatieve geschiedenis' toebedeeld krijgen, omdat men daar althans met de stof mag omgaan, die de sociale wetenschappen op zo wetenschappelijke wijze benaderen. Daardoor zouden de sociale en economische geschiedenis echter hun functie als welomschreven specialismen verliezen en tevens aan betekenis voor de integrale geschiedschrijving inboeten.

Landes en Tilly hebben aangetoond, dat frustraties vooral aanwezig waren bij historici die van sociaal-wetenschappelijke technieken enz. gebruik wensten te maken, maar öf daartoe niet de middelen hadden öf daartoe de opleiding misten. Dat is een probleem dat steeds meer zal gaan spelen met name voor de sociaal en economisch historici en de historische demografen. En laten wij ons zelf niets wijs maken: het is binnen de literaire faculteiten niet op te lossen; en ook: een incidenteel beroep op kennis en apparatuur van buiten zet weinig zoden aan de dijk. Géén oplossing is integratie van de geschiedenis in de sociale faculteit: zolang wij niet willen dat zij verschraalt tot een historiserende aspectwetenschap, is dat onaanvaardbaar. Maar wel zullen nauwe geïnstitutionaliseerde banden aangekoopt moeten worden met economen, sociologen enz. De opleiding van economischhistorici, sociaal-historici enz. moet een zaak worden van historici en economen enz. gezamenlijk. Dan pas is een 'social-scientific' beoefening van de sociale en economische geschiedenis mogelijk, omdat immers voorwaarden hiervoor zijn intensief contact met de collega's van de sociale wetenschappen en het beschikbaar zijn van de nodige apparatuur.

Of de vakgroep (subfaculteit) geschiedenis dan wel de sociale faculteit enz. voor de opleiding van sociaal-historici enz. als formeel onderdak moet dienen, laat ik in het midden. Ook al zou men voor het laatste kiezen - waarvoor veel te zeggen zou zijn- dan moet de desbetreffende opleiding mede een zaak van de historici blijven. De sociaal-wetenschappelijk georiënteerde historici behoeven zich, bij een dergelijk licht samenwerkingsverband, niet meer geïsoleerd en daardoor gefrustreerd te voelen. Zij kunnen dan zelfs naar twee kanten nuttig zijn: naar de kant van de zich historiserende sociologie en naar de kant van de collega-historici die, ieder in hun tijdvak of 'area', een integrale geschiedschrijving op hun program hebben staan. Ik acht het niet uitgesloten, dat men uit vrees voor nog meer verwarring en irritatie geneigd is kwesties als deze als minder urgent in de ijskast te zetten. Maar het is hier niet de plaats om er verder over uit te weiden. Eén ding echter moet me toch van het hart: als een op de totaliteit van het menselijk bestaan gerichte wetenschap hoort de geschiedenis, met de wijsbegeerte, thuis in een centrale interfaculteit ${ }^{28}$.

De door de OSGN geformuleerde vraag was: Is er een crisissituatie en zo ja, is zij dan van conjuncturele of van structurele aard? Mijn antwoord kan niet anders zijn dan dit: vooral in de sociaal-economische hoek is men geneigd om, redenerend vanuit eigen onbehagen, te concluderen tot het bestaan van een crisis van structurele aard. Ik meen echter, met Von der Dunk, dat zolang er om methodieken getwist wordt, we te doen hebben met een

28. In het CS van de NRC (11-1-1974) betoogt dr. J. Stellingwerff in zijn essay 'De universele universiteit' hetzelfde. 


\section{OFFRINGA}

periodieke verjongingskuur; maar ik meen óók, dat wanneer wij ons bepalen tot de methode-Coué, een omslag dreigt van conjuncturele in structurele crisis, waarbij we een goede kans lopen - om met Landes en Tilly te spreken - 'our historical souls' te verliezen. Ter afsluiting van deze beschouwing wil ik de overige bijdragen tegen de achtergrond van de gegeven vraagstelling en mijn daarbij aanknopend betoog plaatsen. M. C. Smit, hoogleraar in de wijsbegeerte van de geschiedenis en in de middeleeuwse filosofie en neoscholastiek aan de Vrije Universiteit te Amsterdam, en J. H. J. van der Pot, die de wijsbegeerte der geschiedenis in Leiden doceert, geven beide een betoog vanuit historistische posities. (Ik wrijf hun natuurlijk geen historistische ideologie aan!) In zijn 'Kanttekeningen bij de huidige discussie over de plaats der geschiedenis' stelt Smit vast dat de grondproblemen dezelfde gebleven zijn. Dat is ook de teneur van mijn betoog. Alleen ik zeg: vroeger kwam men niet verder dan het recept, nu wil men het drankje! Smit beperkt zich vervolgens tot het aanstippen van vier 'moeilijkheden' bij de generaliserende benadering van de geschiedenis. Hij meent dat ook Febvre c.s. de menselijke vrijheid, de eenmaligheid van de individu te kort doen. De Amsterdamse filosoof eindigt met de vraag ('de knuppel in het hoenderhok') of het niet tijd wordt weer eens het oude probleem van de zin der geschiedenis aan de orde te stellen.

Van der Pot geeft, rustig betogend, in een zeker voor studenten informatief stuk zijn visie op 'De zin van de beoefening der geschiedenis'. Zijn argumenten zijn bekend, maar ze zijn er niet minder juist om. Zijn pleidooi voor 'zuivere wetenschap' lijkt mij zeer opportuun.

Vanzelfsprekend is men zeer benieuwd naar wat B. H. Slicher van Bath, emeritus hoogleraar in de agrarische geschiedenis te Wageningen, eminent beoefenaar van de kwantitatieve geschiedenis, op de gestelde vraag zal antwoorden. Hij beperkt zich uitdrukkelijk tot het historisch onderzoek. In 'Historisch onderzoek: conjuncturele of structurele verandering?' maakt hij heel nuchter de balans op. Boven termen als 'crisis' en 'depressie' geeft hij de voorkeur aan het meer neutrale 'verandering'. Zijn eindoordeel verdient in extenso geciteerd te worden:

Samenvattend luidt de conclusie, dat de structurele verandering is opgetreden of zich nog zal manifesteren bij bepaalde vormen van organisatie van wetenschappelijk onderzoek, bij het gebruik maken van een enkele soort van apparatuur, bij enkele onderzoekthema's en bij toepassing van bepaalde aan andere wetenschappen ontleende methoden. Overigens dient opgemerkt te worden, dat de mogelijkheden van structurele veranderingen in het Nederlands historisch onderzoek binnen beperkte grenzen liggen tengevolge van gebrek aan goed bronnenmateriaal. In het overige historisch onderzoek - en dat is vermoedelijk kwantitatief nog een zeer groot deel - voltrekt zich een conjuncturele verandering, het steeds voortgaande vernieuwingsproces. Een toekomst met minder radicale wijzigingen en ook minder grootse perspectieven dan sommigen hopen en verwachten. Wellicht is dit een geruststelling voor de bevreesden.

In de discussie over de veranderingen in het historisch onderzoek zal men in de gedachte moeten houden, dat er steeds Einzelganger zullen blijven, die door hun inspiratie en individuele visie even waardevolle bijdragen tot het begrip van het verleden kunnen leveren als onderzoekers in teamverband.

Aldus Slichter van Bath.

In zijn gedegen verhandeling 'Over geschiedwetenschap en historisch besef' benadert F. R. Ankersmit, als wetenschappelijk medewerker verbonden aan het Historisch Instituut 
te Groningen, de problematiek vanuit een dubbele vraagstelling. De eerste vraag luidt: In hoeverre hebben de historici zélf op louter 'binnenhistorische gronden' hun twijfels aan de traditionele methodes en aanpak? Zijn antwoord: Gezien kwantiteit en kwaliteit der productie is er geen reden om van een crisissituatie te spreken. Maar als men 'de onzekerheid' die bij de historici zelf leeft als criterium aanlegt, dan is dat waarschijnlijk wèl het geval. Ook Ankersmit stelt onwetendheid die tot onzekerheid leidt, vast. Alleen, hij zoekt die op wetenschapstheoretisch gebied. Hij wijst erop, dat van logisch-empiristische zijde vele argumenten zijn aangevoerd voor de wetenschappelijkheid van de traditionele geschiedschrijving, maar dat merkwaardig genoeg de 'humanistische' historici 'weinig op de hoogte schijnen te zijn van de hulp en morele steun die hun door de logisch-empiristen geboden wordt'. Reeds dit zou - meen ik - al voldoende reden moeten zijn om voor een zekere wijsgerige scholing in het leerprogramma plaats in te ruimen. De tweede vraag luidt: Werkt 'het huidige intellectueel klimaat' een crisisgevoel in de hand?

Ofschoon Ankersmit beantwoording van die vraag min of meer 'koffiedikkijkerij' vindt - en onder dat voorbehoud - gelooft hij toch te mogen spreken van een aanstaande 'death of the past'. Niet omdat, zoals Plumb beweert, onze vertechniseerde maatschappij licht met het historisch gegroeide breekt, maar omdat het metafysisch oordeel ('metafysisch paradigma') 'mens en maatschappij zijn historische zijnden', dat sinds ca. 1750 ons historisch denken is gaan bepalen, opzijgedrongen wordt door het paradigma van de jaren daarvóór, 'de mens is een zedelijk wezen'29. Aanvaardt men het tweede paradigma dan zal men niet meer zoeken naar 'de contextuele gebondenheid van het menselijk doen en laten', maar naar de 'zedelijke motieven' van menselijk handelen. In dit licht bezien - aldus Ankersmit - is de strijd tussen Schlosser en Ranke er niet een tussen wetenschappelijkheid en moraliseren, maar tussen twee metafysische paradigma's, waartussen op binnenwetenschappelijke gronden niet gekozen kan worden. Een uitspraak waarbij ik vragen voel rijzen, zoals bijvoorbeeld die naar wat Ankersmit in dit verband onder 'binnenwetenschappelijk' verstaat.

Ankersmit beoordeelt een dergelijke ontwikkeling niet bij voorbaat negatief: 'het zou goed kunnen zijn, dat men liever naar de juistheid van het menselijk handelen en denken dan naar de gebondenheid van dat handelen en denken aan de context waarin het plaatsvond, vraagt'. Hij acht het ook niet uitgesloten - ik trouwens óók niet - dat men eens zal spreken over de negentiende en twintigste eeuw als de eeuwen van het 'socio-historisch besef'. Daar die uitspraak natuurlijk alleen maar uit een ander besef gedaan zou kunnen worden, heeft het zin na te gaan welke tekenen van een dergelijke ontwikkeling Ankersmit heeft waargenomen. Welnu, neo-marxistische uitwassen, structuralistische malaise, veldwinnende invloed van 'de toch wel a-historische, logisch gerichte Angelsaksische filosofie', maar vooral 'de recente renaissance van het natuurrecht' zijn hem evenzovele indicaties voor de juistheid van zijn prognose.

Mag ik tegenover Ankersmits 'koffiedikkijkerij' de mijne stellen? Ik zou dan het volgende willen aanvoeren: 1) in de sociale wetenschappen stijgen de papieren van de 'historiciteit'; 2) Stephen Toulmin constateert hetzelfde op het terrein van het wijsgerig denken over de natuurwetenschappen. In een artikel 'Rediscovering History' van 1971, roept hij uit: Vergelijk eens de boeken van de Hempels, Carnaps, Braithwaithes en Nagels uit de jaren vijftig met die welke nu op dit gebied verschijnen ${ }^{30}$; 3 ) de belangstelling voor het marxisme onder studenten is mede toe te schrijven aan de historistische inslag van deze leer der

29. Verderop spreekt Ankersmit over 'de mens als redelijk wezen'. Hij bedoelt waarschijnlijk 'de mens als redelijk en zedelijk wezen dat zich naar absolute normen behoort te gedragen'.

30. Encounter (Januari 1971) $53 \mathrm{vlg}$. 


\section{OFFRINGA}

sociale dynamica; 4) wij kunnen onze onschuld van vóór het historisme niet herwinnen. De studie van het natuurrecht kreeg door Hitleriaanse 'Umwertung aller Werte' een sterke impuls, maar de vraag is of die impuls niet zal verflauwen; een recensent van het door Ankersmit in een noot genoemde boek van John Rawls, A Theory of Justice (Oxford, 1972), merkt op dat deze 'justice' primair 'a virtue of social institutions rather than of individual people' is; en voorts dat Rawls zich bewust beperkt heeft tot'social justice within a single society $^{\prime 31}$. Maar nogmaals: ik stel slechts mijn indicaties tegenover die van Ankersmit.

Tot hiertoe heb ik de bijdragen tot deze bundel zonder moeite in betrekking tot de voorgelegde vraag kunnen brengen. Met de twee resterende beschouwingen weet ik echter niet goed raad. Fr. de Jong Edz., hoogleraar in de nieuwste geschiedenis aan de sociale faculteit van de universiteit van Amsterdam, schrijft in zijn 'Kleine Historiologie', 'tegen het verleden' ('Een ieder beoefent altijd geschiedenis, zolang hij in leven is, in de hem toegemeten tijd'), 'tegen het incidentalisme' (om daarvan af te komen moeten we 'iets als het begrip verzameling van de wiskunde stelen, dacht ik'), 'tegen het specialisme' (de geschiedenis moet een interdisciplinaire wetenschap zijn, moet 'sociale geschiedenis' zijn) en 'voor de menselijkheid', met als conclusie: 'Geschiedenis kan het niet stellen buiten het narratieve element'.

Misschien moet men de turbulente Amsterdamse sfeer ervaren hebben om de zin te begrijpen van een uitspraak als: 'Beoefening van de geschiedenis is daarentegen het dagelijks door persoonlijk, politiek en sociaal gedrag ingrijpen - een beetje ingrijpen of ook wel laten ingrijpen - in zijn levensomstandigheden'. Kortom: een hoogst merkwaardige concoctie voor hedendaagse kwalen waarin met een beetje goede wil een flauwe smaak te bespeuren valt van Marx, Romein en een bepaald soort activisme dat het noch met de historia noch met de logos erg nauw neemt ${ }^{32}$.

E. E. G. Vermeulens ${ }^{33}$ 'Prolegomena tot een Romeinstudie' is een gemiste kans. Niets over wat Romein als marxist, als dialecticus, als beoefenaar van de integrale geschiedschrijving ons nu nog te zeggen heeft! Alleen een aantal tips voor een 'Romeinstudie' die slechts waarde hebben voor hem die ze geeft; anders gezegd: een reeks open deuren, waardoor wij Vermeulen gaarne zelf zouden zien binnengaan.

Laat ik mijn beschouwing eindigen met mijn waardering uit te spreken voor het constructieve initiatief van de OSGN waarvan deze bundel het in menig opzicht zo nuttige, ja soms verrassende, resultaat is. Echter, wèl nog deze kritische opmerking: ik had graag een practiserend marxistisch historicus over al deze zaken gehoord. Het wordt tijd, dat ons ook vanuit die hoek klare wijn geschonken wordt. Maar misschien is dat iets voor een volgende OSGN Wetenschappelijke Publikatie.

31. Encounter (November 1973) 73 en 76. Ik wil hier bovendien naar aanleiding van Ankersmits uitspraak dat de 'a-historische, logisch gerichte Angelsaksische filosofie zijn invloedssfeer voortdurend ziet uitbreiden', opmerken dat Bryan Magee - de Fons Elders van Engeland - in zijn bundel gesprekken met Britse filosofen (waaronder Ayer, Ryle, Popper) meent te kunnen constateren dat er in Engeland zelf geen 'prevailing orthodoxy' meer is, en zijn gesprek met Anthony Quinton aldus samenvat: we begonnen omstreeks 1900 met een hegeliaanse orthodoxie en nu - in de '1970's' - zien we dat de 'intelligent young' zich weer voor de Duitse idealisten (niet alleen Hegel en de jonge Marx) gaan interesseren. Zie Bryan Magee, ed., Modern British Philosophy (Londen, 1973) 7 vlg. en 29.

32. Ik herinner in dit verband aan De Jongs gesprek met Schöffer, beiden leerlingen van Romein, naar aanleiding van het conflict onder de Amsterdamse politicologen, in Vrij Nederland van 24 maart 1974.

33. Vermeulen doceert theoretische geschiedenis en wetenschapsfilosofie aan de Sociale faculteit van de GU te Amsterdam. 


\title{
Privé-financiële structuren en methodologische problemen Naar aanleiding van publikaties betreffende de Zuidelijke Nederlanden en het Luikse (veertiende tot achttiende eeuw)
}

\author{
L. V A N B U Y T E N
}

De sectie Geschiedenis van het zesentwintigste Vlaams Filologencongres, dat plaats vond te Gent van 29 tot 31 maart 1967, had als algemeen thema gekozen 'Bronnen en methoden voor de studie van de vermogensgroepen van de late Middeleeuwen tot de negentiende eeuw $^{\prime 1}$. Dit gelukkig initiatief had zijn aanzet gevonden (geen inspiratie, want ook hier te lande hield men zich sedert lang met dergelijke onderzoekingen bezig!) in het op 15 en 16 mei 1965 te Saint-Cloud, onder het voorzitterschap van E. Labrousse gehouden Colloque d'histoire sociale ${ }^{2}$. Te Gent had R. van Uytven het in een brede en synthetiserende zin over de methode en over de verschillende mogelijkheden van de aanpak van een studie der stedelijke vermogensgroepen; ofschoon hij in zijn betoog vooral de veertiende tot en met de zestiende eeuw in het oog hield, mag beweerd worden dat zijn beschouwingen vaak ook voor de zeventiende en voor de achttiende eeuw valabel zijn. Hij pleitte enerzijds voor een 'impressionistische' (bedoeld wordt: over alle mogelijke facetten handelende en niet alleen een statische) beoefening der sociale geschiedenis en anderzijds voor de inschakeling of voor de situering van de afzonderlijk onderzochte gevallen (personen, families, groepen) in een soort financiële gradatie der individuen binnen een bepaalde stad, een gradatie verkregen op basis van een bewerking der zogenoemde 'capitatiebe-

1. De tekst der referaten en hun bespreking vindt men in de Handelingen van het XXVIe Vlaams Filologencongres (Gent, 1967): R. van Uytven, 'Bronnen en methoden voor de studie van de vermogensgroepen in de steden (14e-16e eeuw)', ibidem, 377-393 (recensie in BGN, XXII (1969) 353); J. Craeybeckx, 'Stedelijke bronnen voor de studie van de vermogensgroepen in de 18e eeuw', ibidem, 394-402 (recensie in BGN, XXII (1969) 368); J. Hannes, 'Kwantitatieve methode en sociale geschiedenis', ibidem, 402-407 (zie ook idem, 'L'histoire sociale: problèmes de methode et application aux sources bruxelloises du XIXe siècle', Cahiers bruxellois, X (1965) 240-267, zie BGN, XXII (1969) 415 en H. Balthazar, J. de Belder, J. Hannes en J. Verhelst, Bronnen voor de sociale geschiedenis van de XIXe eeuw (1794-1914). Interuniversitair centrum voor hedendaagse geschiedenis. Bijdragen, XVIII (tweede bewerkte en aangevulde uitgave; Leuven-Parijs, 1965); Th. van Tijn, 'Sociale geledingen in Amsterdam, ca. 1855-1891', ibidem, 407-415.

2. Gepubliceerd als L'histoire sociale. Sources et methodes. Colloque de l'école normale supérieure de Saint-Cloud (15-16 mai 1965) (Parijs, 1967). Ook het colloquium van 1966 in de Sorbonne, ingericht door professor R. Mousnier, was aan deze problematiek gewijd: R. Mousnier, ed., Problèmes de stratification sociale. Actes du colloque international (1966). Publications de la Faculté des Lettres et Sciences humaines de Paris-Sorbonne, reeks Recherches, XLIII (Parijs, 1968).

Reeds op het Internationaal congres der historische wetenschappen te Rome in 1955 had E. Labrousse belangstelling gevraagd voor de studie der vermogensgroepen tijdens de achttiende en negentiende eeuw: 'Voies nouvelles vers une histoire de la bourgeoisie occidentale aux XVIIIème et XIXème siècles (1700-1850)', Comitato internazionale di scienze storiche. X congresso internazionale di scienze storiche. Roma 4-11 settembre 1955. Relazioni, IV, Storia moderna (Florence, 1955) 365-396. Het discussieverslag in: Atti del X congresso internazionale Roma 4-11 settembre

1955. Comitato internazionale di scienze storiche (Rome, 1957) 514-530. 